\title{
PIECDESMIT GADU ZINĀTNĒ
}

Pēc Rīgas 3. vidusskolas pabeigšanas 1949. gadā uzsāku studijas LU Medicīnas fakultātē. Ar zinātnisko darbu sāku nodarboties 1951. gada rudenī, kad, strādādama diagnostikas pulciṇā profesora Nikolaja Skujas vadīibā, mērīju asinsspiedienu rūpnīcas VEF strādniekiem dažādos cehos, kā arī pārbaudīju asinsspiedienu Paula Stradina Klīniskās slimnīcas pacientiem vienmērīga trokšna ietekmē.

Par savu skolotāju zinātnē uzskatu profesoru Kristapu Rudzīti, kura vadītajā studentu zinātniskajā pulciṇā sāku strādāt 1952. gada rudenī, klūdama par vienu no profesora Kristapa Rudzī̌a saistaudu tuklo šūnu un eozinofilo leikocītu pētniecēm. Uzsāktais zinātniskais darbs izrādijās veiksmīgs. Par to liecina pirmais zinātniskais raksts, kas publicēts 1953. gadā Latvijas PSR Zinātnu Akadēmijas Vēstīs [1]. Saistaudu tuklo šunnu un eozinofilo leikocītu pētijumi turpinājās līdz studiju beigām, t.i., līdz 1955. gadam, kā arī strādājot par ârsti Smiltenes pilsêtas un Vāles lauku slimnīcā (no 1955. gada augusta līdz 1956. gada oktobrim). Tie turpinājās arī tad, kad strāđāju par zinātnisko līdzstrādnieci Latvijas Eksperimentālās un klīniskās medicīnas institūtā (no 1956. gada oktobra līdz 1979. gada februārim) aptuveni līdz 1963. gadam, tikai tad šiem novērojumiem pievienojās perifērisko asiņu formelementu, seruma olbaltumu un aminoskābes triptofăna pētījumi. Dạ̧a šo pētījumu rezultātu minēta K. Rudzī̌sa monogrāfijā "Гenapuночиumbl"[2], da]a publicêta zinātniskajos rakstos, bet interesantākie apkopoti pirmajā disertācijā medicīnas zinātṇu kandidāta grāda iegūšanai "Perifêrisko asiṇu un saistaudu formelementi un seruma olbaltumi pie laundabigiem audzējiem (klīniski un eksperimentāli pētījumi)" [3], kas aizstāvēta terapijas specialitâtē Rīgas Medicīnas institūta Zinātniskajā padomē 1960. gada 19. decembrī. Maskavas Augstākā atestācijas komisija aizstāvēto medicīnas zinātnu kandidāta grādu apstiprināja 1961. gada 15. februârī. Śajā darbā aprakstīta sakarība starp triptofāna daudzumu seruma albumīnu frakcijā (albumīnu frakcija iegūta ar izsālī̌sanas metodi un saturēja albumīnos esošo, ar albumīniem saistîto, kā arī brīvo triptofānu) un perifêrisko asinu leikocītu skaitu. Tas deva pamatu izvirzìt domu, ka neaizstājamā aminoskābe triptofầns var ietekmēt leikocītu skaitu un formulu, tâpēc to varētu izmantot leikopễniju ârstēšanā. Domas pareizību apstiprināja vienlaikus veiktie ungãru zinātnieku pētījumi [4,5]. Šie autori bija injicējušsi $10 \mathrm{mg} / \mathrm{kg}$ 
ķermeņa svara aminoskābes (glicīnu, izoleicīnu, glutamīnskābi, treonīnu, metionīnu, cistīnu un triptofănu) baltajām žurkām un tikai pềc triptofăna injekcijas novērojuši leikocītu skaita palielināšanos perifēriskajās asinīs, it īpaši 24 . stundā.

Darba turpmāko virzỉbu tuklo šūnu pētīšanā kavēja jaunas metodes izstrādāšanas nepieciešamība. Tāpēc pievērsos neaizstājamās aminoskābes triptofăna pētījumiem. Par kandidāta disertācijas darbā veikto pētījumu rezultātiem sagatavoju pirmo publikāciju ang|u valodā, ko publicēja žurnāls Neoplasma [6]. Bez tam uzsāku triptofăna lietošanu pazemināta leikocītu skaita gadījumos gan klīniski veseliem cilvēkiem (rentgenkabinetos strādājošiem), gan arī slimniekiem. Tā kā triptofăna dienas deva pieaugušajam cilvēkam ir $0,5-1,0 \mathrm{~g}$, tad triptofănu ordinēju perorāli pa $0,1 \mathrm{~g}$ dienā ěšanas laikā 10 dienas pēc kārtas, Iegūtos rezultātus apkopoju zinātniskā rakstā, ko 1963.gadā publicēja Latvijas PSR Zinātṇu Akadēmijas Vēstis [7].

Turpmāk pārbaudīju triptofāna abu optisko izomēru, kā arī racemāta darbību. Bez tam veicu lielu eksperimentu, kurā pēc triptofăna parenterālas ievadī̌sanas dzīvniekiem (baltajām Wistar līnijas žurkām) kontrolēju ne vien asins formelementu skaitu, bet arī triptofăna oksigenāzes un 5-hidroksitriptofăna dekarboksilāzes aktivitāti aknās. Ja triptofâna oksigenāze nosaka kinurenīna, tad 5hidroksitriptofâna dekarboksilāze - serotonīna biosintēzi (1. att.). Tã kâ iezīmējās paralēles starp minēto fermentu aktivitāti aknās no vienas puses un perifērisko asiṇu formelementu skaitu no otras puses, izvirziju domu, ka fiziologiski aktīvs ir ne tikai triptofăns, bet arī tă metabolĩti. Turpmākie pētījumi parādīja, ka tādi metabolìti, kā kinurenīns un serotonīns ne tikai palielina leikocîtu skaitu perifêriskajās asinīs, bet arī triptofăna oksigenāzes aktivitāti aknās: tātad tie aktivē kinurenīna biosintēzi. Šāds fakts bija konstatēts pirmo reizi [8]. Tikai 1972. gadā šo novērojumu apstiprināja vācu zinātnieks Hardelands [9], ziņojot, ka kinurenīns, 3-hidroksiantranilskābe, hinolīnskābe, pikolīnskābe, kinurenīnskābe, hinaldīnskābe un ksanturēnskābe paaugstina gan triptofăna oksigenāzes, gan arī tírozīna aminotransferāzes aktivitāti aknās. Iegūtos pêtījumu rezultătus 1968. gadā apkopoju otrajā disertācijā - "Особенности обмена триптофана при патологии" [10] -, lai iegūtu medicīnas zinātṇu doktora grādu. Disertāciju aizstāvêju patofiziologijas specialitātē 1969. gada 14. oktobrī PSRS Medicīnas Zinātṇu Akadēmijas Fiziolog̉ijas, bioḳīmijas un farmakolog̉ijas zinātniskajā padomē Maskavā. PSRS Augstākā atestācijas komisija aizstāvēto grādu apstiprināja 1971. gada 19. februārī, bet 1992. gada 17. jūnijā Latvijas Eksperimentālās un klīniskās medicīnas institūta Habilitācijas un promocijas padome to nostrificēja, pieškirot medicīnas habilitētā doktora grādu. Profesora titulu pieškịira Latvijas Kardiologijas institūta Zinātniskā padome 1993. gada 13. oktobrī. Doktora disertācijas darbā iegūtos rezultātus apkopoju monogrāfijā "Tpunmoфaн (в норме и патологиu)" [11]. Jāatzīmē, ka tā bija pirmā grāmata, kas veltīta neaizstājamai aminoskābei triptofănam. 
Kad pēc doktora disertācijas aizstāvēšanas atgriezos Rīgā, docents Valentīns Būmeisters mani lūdza palīdzēt eksperimentāli pierādīt viṇa izvirzìto hipotêzi, ka palielināts og|skābās gāzes saturs ieelpojamā gaisā ietekmē vairogdziedzera funkciju un apmērus skolēniem. Šĩ hipotēze bija izvirzīta pēc skolēnu apsekošanas dažādās Latvijas skolās vairāku gadu garumā. Šajā laikā Valentīns Būmeisters vadīja Endokrinologijas laboratoriju, kurā biju izstrādājusi savu doktora disertāciju un kurā turpināju strādāt. Bez tam viṇš bija vadījis manu subordinatūru 6. kursā un devis daudz vêrtīgu padomu praktiskajā medicīnā. Tāpēc ar prieku pieṇēmu šo lūgumu, kura veikšanai pagāja trīs emocionāli smagi, bet darba ziņā spraigi un interesanti gadi. Latvijas Eksperimentālās un klīniskās medicīnas institūta vadošās amatpersonas V. Būmeistera hipotēzei neticēja un, šķiet, uzskatīja uzsākto darbu par laika un līdzek|u nelietderīgu izmantošanu. Bez tam tajā laikā Rīgā lietoja tikai divas metodes vairogdziedzera funkcionālā stāvokja noteikšanai: klīnisko un J131 uzkrāšanās metodi vairogdziedzerī. Vairogdziedzera funkcionālā stāvok]a noteikšanai dzīvniekiem abas minētãs metodes nebija lietojamas. Tā kā mūsu tehniskās iespējas laboratorijā bija visai ierobežotas, izstrādāju ar proteīniem saistītā joda noteikšanas metodi asins serumā [12]. Darbā iesaistīju Rīgas Medicīnas institūta darbiniekus: Histologijas katedras vadītāju profesori Ainu Dālmani un šās katedras vecāko laboranti Lolitu Osīti. Darbs vainagojās panākumiem: palielināts og|skābās gāzes saturs ieelpojamā gaisā palielināja vairogdziedzera apmērus un svaru baltajām Wistar līnijas žurkām, bet, spriežot pēc ar proteīniem saistîtā joda daudzuma asins sērumā, samazināja tā aktivitāti [13, 14]. Pašreiz šo darbu turpina profesore Renāte Ligere, kura šobrīd apsekojusi 1049 Latvijas skolēnu vielmainas traucejumu îpatnības, tomēr iegūtos rezultātus pagaidām nav publicējusi.

Darbu vajadzēja turpināt arī aizstāvētās disertācijas virzienā. To savos noteikumos par doktora grāda pieškiršanu bija norādījusi PSRS Augstākā atestācijas komisija. Kad 1975. gadā literatūrā parādījās pirmā un pagaidām vieniggā kolorimetriskā metode kinurenīna noteikšanai, izstrādāju to un ieviesu turpmākajā darbā [15]. Šajā laikā laboratorijā strādāja Latvijas Valsts Universitātes K̦īmijas fakultātes studente Inta Siliņa (tagad Muižniece), kas ar jonu maiņas sveḳu hromatogrāfijas metodi centās noteikt gan kinurenīnu, gan 3-hidroksikinurenīnu. Arī šis darbs vainagojās panākumiem. Tã kā Inta Siliṇa bija sportiste un îsajās distancēs skriešanā bija ieguvusi 3. vietu Latvijā, diplomdarbam ieteicu pārbaudīt triptofăna līmeni asinīs un kinurenīna līmeni urīnā skrējējiem pirms un pēc treniṇa. Pēc 45 minūšu ilgas skriešanas konstatējām brīvā triptofăna daudzuma paaugstināšanos asins serumā un kinurenīna daudzuma pieaugumu urīna [16]. Šãds fakts bija konstatēts pirmo reizi. Izskaidrojumu tam toreiz nezinājām, nezinājām arī par kinurenīna fiziologisko aktivitāti. Tomēr bija zināms, ka kinurenīna metabolītiem 3-hidroksikinurenīnam un 3-hidroksiantranilskābei piemīt endogēna blastomogēna aktivitāte. Tāpēc, lai nekaitễtu sporta attīstībai Padomju Savienībā, datu publicē̌̉anu aizliedza. Šie rezultāti publicēti tikai 1999. gadā [17], kad bijām jau iegu- 
vuši datus par kinurenīna ietekmi uz sirds un asinsvadu sistēmu, kad bija zināms, ka skrējējiem un riteņbraucējiem sacīkšu laikā dramatiski izmainās imūnsistēma [18] un kinurenīna līmenis asins serumā pieaug pēc regbija cīṇām un arī veloergometrijas[19].

Ar Latvijas PSR Veselības aizsardzības ministrijas pavēli 1979. gada 5.februârī mani pārcēla darbā par vecāko zinātnisko līdzstrādnieci uz 1977. gadā dibināto Latvijas Kardiologijas institūtu. Nācās uzbūvēt laboratoriju (jau 4. pēc kārtas). Tagad arī ši - mana labākā laboratorija - ir iznīcinăta. Savus pētịjumus turpinām trīs nelielās telpās, kuras būtu dēvējamas par 5. laboratoriju.

Ceturtās laboratorijas iekārtošanas laikā uzrakstīju otru monogrāfiju "Диабетогенные метаболиты триптофана как причина сахарной болезни." То рublicēja Latvijas PSR izdevniecība Zinātne 1981. gadā [20]. Ar šo mazo grāmatinu atvadījos no Latvijas Eksperimentālās un klīniskās medicīnas institūta, kurā biju strādājusi gandrīz 23 gadus.

Kardiologijas institūta vadība bija labvēlīgi noskaņota un tālredzīga, jo at|āva pētīt triptofăna-nikotīnskābes mainas celu kardiolog̀ijas slimniekiem. Pretimnākoša izrādījās arī PSRS Valsts Zinātnes un tehnikas komiteja, kas apstiprināja iecerētā darba têmu un piešķīra finansējumu, zinot, ka literatūrā datu šajā virzienā nav. 1981. gadā Kardiolog̉ijas institūtā nodibināja Bioḳīmijas laboratoriju, par kuras vadītāju ievēlēja mani. Tã sākās vissatraucošākais un interesantākais posms manā darba dzīvẽ: "staigāšana pa baltu lapaspusi medicīnas zinātnē". Tāpēc turpmāk iegūtie rezultāti parasti bija jauni, pasaules literatūrā vēl neaprakstîti. Pēc laboratorijas nodibināšanas uzaicināju darbā ķīmiķus. Vienlaikus ar radioimunologisko metožu lietošanu arteriālās hipertensijas izcelsmes izzināšanai pētijāmm triptofănanikotīnskābes maiñas cẹ̦u slimniekiem ar kardiovaskulāru patolog̉iju. Izcils palīgs darba sākumam bija Paula Stradiṇa Klīniskās slimnīcas 32. noda|as vadītājs Jānis Lācis, kas at|āva izmeklēt slimniekus ar neskaidru diagnozi.

Pirmā veiksmīgā slimniece bija ar nezināmas etiologijas angina pectoris lēkmēm naktīs, miera stāvoklī. Parasti lietojamā terapija lēkmes nesamazināja. Jaundibinātajā laboratorijā atrada izteiktu kinurenīna akumulěsanos asins serumā pēc perorālas $30 \mathrm{mg} / \mathrm{kg}$ k kermeña svara L-triptofăna slodzes. Šāda parādība literatūrā aprakstīta kā B6 vitamīna aktīvās formas jeb piridoksāl-5-fosfăta (P-5-F) nepietiekamība organismā [21]. P-5-F biosintēze parādìta 2. attēlā. Tâpēe slimniecei ieteicu lietot maksimālas piridoksīna un riboflavīna devas, kā arī nikotīnskābi, jo tâs biosintēze šãdos apstāklos ir kavêta. Šĩ terapija deva labus rezultātus: slimniece izveselojās. Normalizējās arī kinurenīna akumulēßanās asins serumā. Iegūtie rezultāti veidoja pamatu diviem izgudrojumiem, kurus apstiprināja 1983. gadā $[22,23]$. Tomēr tie neatrisināja divus būtiskus jautājumus: 1) ko slimnieki jūt Šo īpatnējo lēkmju laikā un 2) kāda nozīme ir kinurenīnam šādu angina pectoris lēkmju ġenēzē. Bez tam neviens nezināja, ko jautāt slimniekiem, lai iegūtu nepieciešamo informāciju. Strādājot 10 dienas Maskavā Centrālajā medicīnas 


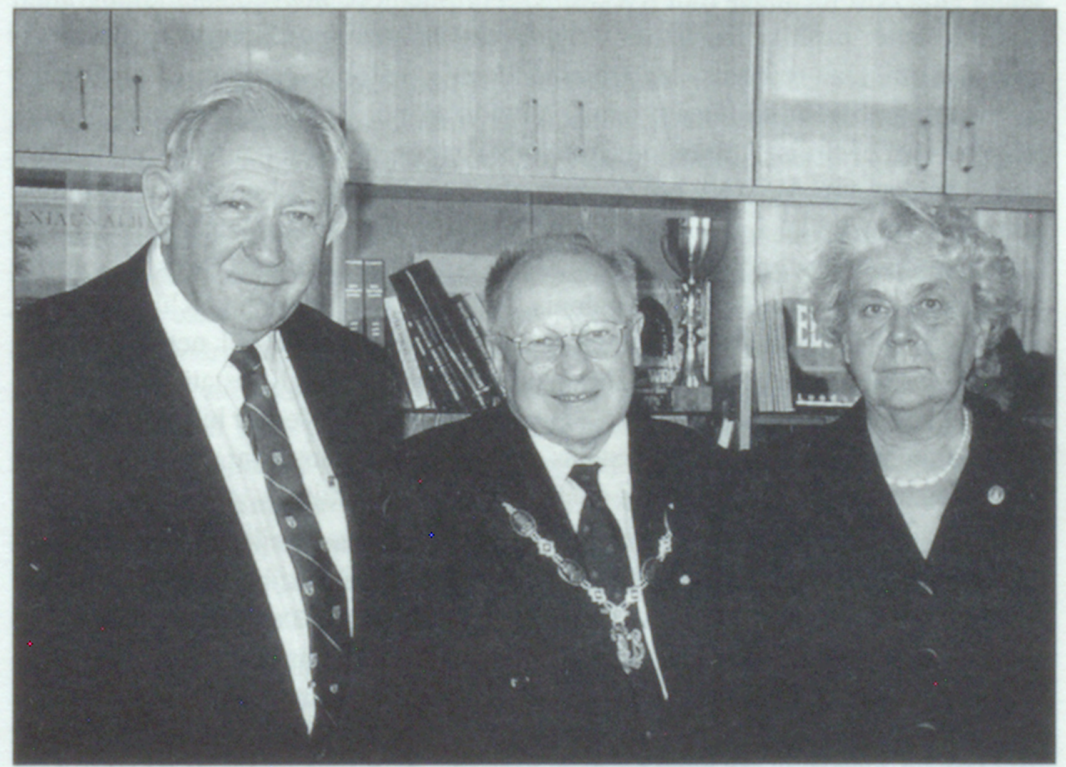

Tikšanās Latvijas Zinātṇu akadēmijā. No kreisās - LZA ârzemju loceklis Sergejs Fjodorovs, LZA prezidents Jānis Stradiṇš, LZA akadēmiḳe Vera Rudzīte 
bibliotēkā un L̨enina bibliotēkā tiešus norādījumus neatradu, tomēr netiešu ziṇu sameklēju: kinurenīna ievadīsana dzīvniekiem galvas smadzeṇu ventrikulos izraisīja krampjus, kas bija līdzīgi epilepsijas lēkmei. Šie krampji dažkārt beidzās ar nāvi - tātad sirds apstāšanos. Secināju, ka nepieciešami izolētas sirds eksperimenti, lai izslēgtu galvas smadzeṇu lomu sirds darbības regulēšanā. Atgriezusies Rīgā, sāku meklēt izolētas sirds pētniekus un turpat līdzās Kardiologijas institūtā atradu Guntu Silenieci, kas prata izolēt vardes sirdi un to neskaitāmas reizes bija darījusi Latvijas PSR Zinātṇu akadēmijas Organiskās sintēzes institūtā, lai pētītu jaunu sintezēto medikamentu ietekmi. Gunta Sileniece nokvēpināja kimogrāfam nepieciešamo papīru, izolēja un sagatavoja farmakologiskam eksperimentam vardes sirdi. Jau pirmais novērojums deva pozitīvus rezultātus: kinurenīna pievienošana barotājsḳ̌īdumam izraisīja bradikardiju. Gunta Sileniece pārbaudīja vēl divas varžu sirdis. Arī tām novēroja bradikardiju pēc kinurenīna pievienošanas barotājšķīidumam. Veiktais novērojums deva iespēju pajautāt jau izmeklētiem slimniekiem, ko viņi izjutuši savu sirds lēkmju laikā - paătrinātu vai palēninātu sirdsdarbību. Visos gadījumos sirdsdarbība bija palēninājusies. Sirds bija apstājusies, kas tad arī bija nāves bailu cēlonis. Tajā laikā Paula Stradinna Klīniskās slimnīcas Kardiologijas noda|ās Holtera monitorēŠanas metode vēl nebija ieviesta. Parastā kardiogrammā bradikardijas lēkmes nenovēroja. Konstatēja hipoksijas pazīmes miokardā, blokādi vienā no Hisa kūlīša zariem. Tomêr bija arī normālas kardiogrammas. Ja slimnieks ārstējās ambulatori, to nosūtīja pie psihiatra, jo neatrada sūdzỉbu cēloni. Psihiatrs diagnosticēja psihopâtiju.

Laika posmā starp diviem dekrēta atva|inājumiem Gunta Sileniece turpināja iesāktos eksperimentus un paguva pārbaudīt ne tikai kinurenīna, bet arī tã metabolītu ietekmi uz izolētas sirds darbību. Gan kinurenīns, gan arī tã metabolīti izraisīja ne tikai bradikardiju, bet arī ekstrasistoliju un sirdsdarbības apstāšanos diastoles sākuma fãzē. Šie novērojumi veidoja pamatu aspiranta Jāṇa Jirgensona disertācijas darbam. Viṇš novēroja slimniekus ar sinusa bradikardiju, sinusa mezgla slimību un hronisku atrioventrikulāro blokādi. Vairākumam šo slimnieku konstatējām paaugstinātu kinurenīna akumulēšanos asins serumā pēc L-triptofăna perorālas slodzes. Šiem slimniekiem novērojām arī pazeminātu triptofăna uzsūkšanos un pazeminātu endogēnās nikotīnskābes veidošanās procesu [24]. Savu disertāciju Jānis Jirgensons aizstāvēja 1986. gadā Minskā un Šobrīd ir viens no vadošajiem kardiologiskā dienesta speciālistiem ne tikai Paula Stradiṇa Universitātes klīnikā, bet arī Latvijā. Otrs aspirants - Jãnis Skārds - izmeklēja kardiomiopātiju slimniekus un novēroja palielinātu kinurenīna akumulēšanos asins serumā hipertrofijas un, it īpaši, dilatācijas kardiomiopātijas slimniekiem. Šiem slimniekiem triptofāna uzsūkšanās un endogẽnās nikotīnskābes veidošanās process bija normāls vai pat paaugstināts [25].

Literatūrā atrodami dati, ka dilatācijas kardiomiopātijas cēloṇi saistāmi ar infekciju. Tāpēc, sākot ar 1989. gadu, Šiem slimniekiem pārbaudijjām neopterīna līmeni asins serumā Insbrukas universitātes Medicīniskās k̦īmijas un bioḳīmijas institūtā. 
Neopterīna līmenis bija paaugstināts. Neopterīns rodas makrofăgos no guanozīna trifosfăta citokīnu, it īpaši gamma interferona ietekmē (3. attēls). To uzskata par stabilu rādītāju infekcijas klātbūtnes diagnosticēšanai. Gamma interferona paaugstinātais līmenis aktivē otru kinurenīna veidojošo fermentsistēmu - indolamīna dioksigenāzi. Triptofăna dioksigenāze atrasta tikai aknu audos, turpretī indolamīna dioksigenāze - visos audos, it īpaši plaušu audos. Tāpēc kardiomiopātijas slimniekiem ir paaugstināts kinurenīna līmenis asins serumā jau tukšã dū̌̃ā, bet nikotīnskābes biosintēze nav traucēta. Jānis Skārds savu disertāciju aizstāvēja 1991. gadā Rīgas Medicīnas institūta Zinātniskajā padomē; šobrīd strādā A/S Linezers un vada Hipertensijas ārstu biedrību Latvijā.

Vienlaikus ar minētajiem klīniskajiem novērojumiem veicām eksperimentālus pētījumus, lai izzinātu kinurenīna ietekmi uz sirds šūnām. Pētījumos piedalījās profesore Aina Dālmane, vecākā zinātniskā līdzstrādniece Ruta Zirne, vēlāk arī nu jau habilitētā medicīnas doktore Valērija Groma. Šajos pētijumos izmantoja gaismas un elektronu mikroskopiju. Gaismas mikroskopā kinurenīna ietekmē novēroja distrofiskas izmaiñas sirds intramurālo gangliju šūnās un kardiomiocītos, bet elektronmikroskopā - sarkoplazmas un intracelulārās spraugas tūsku, uzbriedušus mitohondrijus, izlocītas Z līnijas miofibrillās, sarkomēru superkontrakcijas un miofibrillu sabrukšanu [26]. Šīs izmainas bija līdzīgas tām, kas raksturīgas gadījumiem, kad šūnā pastiprināti uzkrājas kalcijs un sākas kalcijatkarīgā šūnas distrofija. Pateicība par šajos pētijjumos iegūtajiem rezultātiem pienākas ne tikai Latvijas histologiem, bet arī PSRS (tagad Krievijas) Tautu draudzības universitātes Patofiziologijas katedras vadītājam profesoram Viktoram Frolovam, kurš, būdams Rīgā, iemācīja mūs pareizi nofiksêt izolētas sirdis, lai izslēgtu iespējamı artefaktu rašanos izmeklējamā parauga paṇemšanas brīdī.

Jautājums, vai kinurenīns pats stimulē kalcija uzkrāšanos šūnās vai citi metabolīti, kuri akumulējas audos un šūnās kinurenīna ietekmē, pagaidām nav noskaidrots. Mũsu pētījumos pēc kinurenīna pievienošanas izolētas sirds barotājš̌sīdumam novērojām paaugstinātu noradrenalīna līmeni izolētās sirds audos. Zināms, ka noradrenalīns izraisa kalcija uzkrāšanos kardiomiocītos [27]. Tad šūnu izmaiņas elektronomikroskopiski ir līdzīgas tām, ko esam novērojuši kardiomiocītos pēc kinurenīna pievienošanas izolētas sirds barotājškşīdumam [26].

Darbs Kardiologijas klīnikā neaprobežojãs tikai ar slimnieku izmeklēšanu Paula Stradiṇa Klīniskās slimnīcas 32. un 26. noda|ā. Slimniekus izmeklējām arī 27. noda|jā, kur ārstējās cilvēki ar paaugstinātu asinsspiedienu. Izrādījās, ka arī dalai hipertonijas slimnieku bija palielināta kinurenīna akumulēšanās asins serumã pēc perorālas L-triptofāna slodzes. Triptofăna uzsūkšanās un endogēnās nikotīnskābes veidošanās process viniiem bija pazemināts. Tâtad novērotãs izmainas bija galvenokārt saistāmas ar P-5-F nepietiekamību organismā. Ja literatūras dati liecināja, ka triptofăna sloze pazemina asinsspiedienu hipertonijas slimniekiem [28], tad slimniekiem ar paaugstinătu kinurenīna akumulēšanos asins serumā pēc perorālas triptofăna slodzes asinsspiediens paaugstinājās. Lai atšifrētu šo novērojumu, labo- 
ratorijas ķīmiķe Edīte Jurika izstrādāja kateholamīnu noteikšanas fluorimetrisko metodi, jo šķīduma hromatogrāfu mūsu laboratorija nekad nav varējusi iegādāties. Izrādījās, ka šādiem slimniekiem triptofăna slodzes laikā organismā pastiprināti uzkrājas noradrenalīns. Bez tam konstatējām, ka asins serumā, kas inkubēts termostatā $37^{\circ} \mathrm{C}$ temperatūrā kopā ar kinurenīnu, noradrenalīna līmenis arī paaugstinās. Uzskatījām, ka paaugstinātais kinurenīna līmenis kavē noradrenalīna pāreju adrenalīnā. Tãpēc, lai normalizētu asinsspiedienu, sādiem slimniekiem ieteicām lietot alfa-adrenoblokatorus, kas asinsspiedienu pazemināja. Šajā darbā bez laboratorijas kolektīva piedalījās arī Paula Stradinna Klīniskās slimnīcas ārsts Jānis Arājs [29]. Lai gan darbā iegūtie rezultāti veidoja pamatu mūsu trešajam izgudrojumam, kuru apstiprināja 1988. gadā [30], disertācija ir palikusi neuzrakstīta.

Gadu gaitā novērojot hipertensijas slimniekus ar paaugstinātu kinurenīna akumulēšanos asins serumā pēc triptofăna slodzes, konstatēju, ka šãdiem slimniekiem ir urīna izvades traucējumi, pārbaudot nieru funkciju ar dinamiskās scintigrāfijas palīdzību. Trim slimniekiem ar izteiktu indikāciju un profesora Ilmāra Lazovska palīdzību veicầm nieru biopsiju. Nieru bioptātā histologi atrada izmaiņas, kas apliecināja mezangiālproliferatīvu glomerulonefrìtu. Pēc šì konstatējuma darbā iesaistijās Fakultâtes terapijas katedras aspirants Agris Martinsons, kas turpmākos novērojumus veica Paula Stradiṇa Klīniskãs slimnīcas 8. (nefrolog̀iskā) noda|ā. Izmeklējot slimniekus ar dažādām glomerulonefrīta formām, kā arī slimniekus ar nieru mazspēju, paaugstinātu kinurenīna uzkrāšanos asins serumā pēc L-triptofāna perorālas slodzes novērojām tikai mezangiāliproliferatīvā glomerulonefrīta un nieru mazspējas slimniekiem. Šie novērojumi veidoja pamatu Agra Martinsona pirmajai disertācijai [31], kuru viņš sekmīgi aizstāvēja Rīgas Medicīnas institūta Zinātniskajā padomē 1991. gadā.

Novērojot, ka kinurenīns un neopterīns spēj izraisīt orgānspecifisku šūnu apoptozi, radãs jautājums, kas tad aizpilda bojā gājušo šūnu vietas. To vajadzēja veikt saistaudiem. Tāpēc ar Latvijas PSR Mikrobiolog̉ijas institūta darbinieku palīdzību pievienojām kinurenīnu cilvēka fibroblastu audu kultūrai. Izrādījās, ka kinurenīna ietekmē fibroblastu skaits audu kultūrā nemainījās, bet pieauga $\mathrm{H}^{3}$ timidīnu saturošo fibroblastu skaits [32]. Tas liecināja par fibroblastu potenciālo dalī̌sanās iespēju. Šis konstatējums noderēja Agrim Martinsonam turpmāko pētījumu veikŁanai, jo arī nieru mezangijs ir saistaudi. Iegūtos rezultātus Agris Martinsons varēja apkopot otrā disertācijā [33], kuru aizstāvēja Latvijas Medicīnas akadēmijas Habilitācijas un promocijas padomē 1998. gadā un ieguva habilitētã medicīnas zinātnuu doktora grādu. Šobrīd Agris Martinsons strādā Paula Stradiṇa Universitātes klīnikā, kā arī vada Šīs klīnikas zinātnisko darbu.

Sirds un asinsvadu patologiju pavada izmaiṇas lipīdos. Šīm izmaiṇām pieșkirta viena no galvenām sekundāro faktoru vietām aterosklerozes patogenēzē. Lipīdu izmaiņas daudz pētitas, bet pētijumi vēl turpinās. Kad Kardiologijas institūta Bioḳīmijas laboratorija saṇēma čehu firmas gāzes hromatogrāfu, kas bija paredzēts taukskābju noteikšanai, kolektīivs pievienojās šiem pētījumiem. Iegūtos rezultātus 
ieteicu iedalīt divās grupās: rezultâtos, kas iegūti, izmeklējot slimniekus ar normālu kinurenīna akumulēšanos asins serumā pēc L-triptofāna perorālas slodzes (slimnieki bez P-5-F nepietiekamības), un rezultātos, kas iegūti, izmeklējot slimniekus ar paaugstinātu kinurenīna uzkrāšanos asins serumā pēc L-triptofâna perorālas slodzes (slimnieki ar P-5-F nepietiekamību). Izrādījās, ka asins seruma kopējā holesterīna un augsta blīvuma lipoproteīdu holesterīna daudzuma izmaiñas abās grupās bija aptuveni vienādas: kopējā holesterīna daudzums paaugstināts, bet augstā blīvuma lipoproteīdu holesterīna daudzums pazemināts. Atškirirỉbas starp grupām bija novērojamas triglicerīdu un fosfolipīdu daudzumā. Slimniekiem ar P-5-F nepietiekamību novērojām paaugstinātu triglicerīdu, bet pazeminātu fosfolipīdu daudzumu asins serumā. Pievērsāmies fosfolipīdu pētījumiem. Ar plānā slāna hromatogrāfijas palīdzỉbu konstatējām, ka šādu slimnieku asins seruma fosfolipīdi satur pazeminātu lecitīna (fosfatidilholīna), bet paaugstinātu fosfatidilserīna daudzumu. Tătad bija traucēta fosfolipīdu biosintēze. To apstiprināja arī fosfolipīdu taukskābju spektra analīzē iegūtie rezultāti: P-5-F nepietiekamības gadījumos fosfolipīdos bija paaugstināts piesātināto un pazemināts nepiesātināto taukskābju daudzums. Šādas fosfolipīdu kvalitatīvas izmaiñas bija novērojamas ne tikai asins serumā, bet arī eritrocītu membrānās, kas liecināja, ka lipīdu izmaiṇas asins serumā atspoguḷo novirzes šūnu membrānās. Minētos klīniskos novērojumus pārbaudījām eksperimentā ar dzīvniekiem (baltajām Wistar līnijas žurkām). Tad ar medikamenta izoniazīda palīdzību izraisîjām gan kinurenīnēmiju, gan arī P-5-F daudzuma samazināšanos ne vien asins serumā, bet arī aknu, nieru un sirds audos. Eksperimentā iegūtie rezultāti klīniskos novêrojumus apstiprināja.

Pētot literatūru, noskaidrojām, ka holesterīna/fosfolipīdu attiecỉba, holesterīna daudzums un fosfolipīdu taukskābju spektrs ir galvenie šūnu membrānu fluiditātes regulējošie faktori $[34,35]$. Ja šūnās membrānu lipīdu frakcijā holesterīna/fosfolipīdu attiecỉba un holesterīna līmenis ir paaugstināti un paaugstināts ir arī piesātināto taukskābju daudzums fosfolipīdos, tad šūnas membrānu fluiditāte ir pazemināta, šunas cikls kavēts, šūnā uzkrājas kalcijs, kam seko kalcijatkarīga šūnas distrofija un apoptoze. Bez tam šãdas lipīdu izmaiņas rada labvēlīgus apstāklus holesterīna izkrišanai - tātad aterosklerozes attīstỉbai. Ja šūnas membrānu lipīdu frakcijā holesterīna/fosfolipīdu attiecība un holesterīna daudzums ir samazināts un fosfolipīdi satur paaugstinātu nepiesātinăto, it îpaši polinepiesātināto taukskābju daudzumu, tad šūnas membrānu fluidităte ir paaugstināta, šūnas cikls aktivēts, tomēr iespējama arī šunas transformācija. Holesterīna izkrišana un aterosklerozes attīstība ir kavēta.

Kas nosaka minētās lipīdmainas novirzes? Faktori, kuri aktivē vai inaktivẽ fermentsistēmas vai paaugstinātais metabolītu līmenis, kas radies izteikti aktivētu metabolītu veidojošo un izteikti inaktivētu metabolītu noārdošo fermentsistēmu darbības rezultātā? Šā jautājuma skaidrošanai esam veltijuši pēdējos desmit gadus. Lai pētītu aminoskābju un citu metabolītu ietekmi uz lipīdmaiņu, vajadzēja izstrādāt metodi pētijumiem in vitro, jo apstāklos in vivo metabolīti turpina meta- 
bolizēties. Pateicoties laboratorijas k̦īmiķes Edītes Jurikas sapratnei, metode tika izstrādāta. Tā izrādījās darbietilpīga, tomēr deva ticamus rezultātus. Izdevās noskaidrot, ka tāds fermentsistēmu kofaktors kā P-5-F taukskābju ieslēgšanos fosfolipīdos neizmaina. Nemainījās arī holesterīna un fosfolipīdu daudzums paraugos fosfolipīdu biosintēzes laikā, kā arī holesterīna/fosfolipīdu attiecība. Turpretim, ja P-5-F pievienoja aknu homogenātam, kas iegūts no P-5-F deficīta žurkām, un kura fosfolipīdos bija augsts piesātināto taukskābju saturs, tad novēroja taukskābju spektra normalizēšanos fosfolipīdu biosintēzes laikā. Pēc kinurenīna, tas ir metabolīta, kas uzkrājas asins serumā P-5-F deficīta gadījumos cilvēkam un dzīvniekiem, pievienošanas paraugiem, kas saturēja intaktu žurku aknu homogenātu, taukskābju spektrs, kā arī holesterīna/fosfolipīdu attiecība fosfolipīdu biosintēzes laikā uzrādīja izmainas, kas bija līdzīgas tām, kādas bija konstatētas slimniekiem un dzīvniekiem ar P-5-F nepietiekamību.

Šobrīd pārbaudīta L-triptofầna, visu svarīgāko triptofāna starpvielmaiṇas metabolītu, noradrenalīna, 9 pteridīnu un L-homocisteīna ietekme uz fosfolipīdu biosintēzi in vitro. Esam novērojuši, ka kinurenīns (4. att.), antranilskābe, kinurenīnskābe, ksanturēnskābe, pikolīnskābe, 5-hidroksiindoletiksskābe, noradrenalīns un neopterīns (vienīgais no pārbaudītiem pteridīniem) veicina piesātināto un kavē polinepiesātināto taukskābju ieslēgšanos fosfolipīdos. Biosintēzes laikā holesterīna daudzums paraugos paaugstinās, bet fosfolipīdu daudzums samazinās vai neizmainās. Rezultātā holesterīna/fosfolipīdu attiecība paaugstinās. Šis konstatējums lauj izteikt domu, ka gadījumos, kad minēto metabolītu koncentrācija organismā ir paaugstināta, organisma šūnu membrānu fluidităte pazeminās, šūnās pastiprināti uzkrājas kalcijs, kas var izraisīt kalcija atkarīgo šūnu distrofiju un apoptozi. Arī holesterīna izkrišana un aterosklerozes attīstība var tikt veicināta. Pilnīgi neatrisināts, protams, paliek jautajums par dažādu šūnu jutības iespējamo atšksirību jeb minēto metabolītu specifisko afinitāti.

Kinurenīns piedalās šūnās ieslēgto parazītu (5. att.) iznīcināšanā [36], kã arī kalcijatkarīgajā šunnu distrofijā un apoptozē [26]. Pēdējā procesā piedalās arī neopterīns [37] un noradrenalīns [27]. Kinurenīnskābei un ksanturênskābei piemīt diabetogēna aktivitāte, jo, piesaistīdamas organismā esošo cinku, tās inaktivē insulīnu [20,38]. Šajā procesā palīdzīga izrādās pikolīnskābe, kas kavē cinka uzsūkŠanos no kungia un zarnu trakta [20]. Bez tam pikolīnskābe iedarbojas nāvējoši uz vīrusiem un maligni transformētām šūnām [39]. Pikolīnskābei līdzīgu darbību uz maligni transformētām šunām ir uzrādījusi arī 5-hidroksiindoletiksskābe [11].

Triptofăns, 3-hidroksikinurenīns, 3-hidroksiantranilskābe, hinolinskābe, nikotīnskābe, serotonīns (ja paraugiem pievienots kopā ar monoaminooksidāzes inhibitoru ipraniazĩdu), acetilserotonīns, melatonīns, no pteridīniem -sepiapterīns, dihidrobiopterīns, tetrahidrobiopterīns, dihidroneopterīns, kā arī L- homocisteīns (6. att.) pazemina piesātināto un paaugstina polinepiesātināto, it īpaši arahidonskābes, ieslēgšanos fosfolipīdos. Biosintēzes laikā holesterīna daudzums paraugos pazeminās, bet fosfolipīdu daudzums paaugstinās vai neizmainās. Rezultātā holes- 
terīna/fosfolipīdu attiecība pazeminās. Tātad gadījumos, kad minēto metabolītu koncentrācija organismā ir paaugstināta, organisma šūnu membrānu fluiditāte var palielināties, šūnu cikls aktivēties, tomēr iespējama arī šūnu transformācija. Holesterīna izkrišana un aterosklerozes attīstība varētu tikt kavēta. Protams, neatrisināts paliek jautājums par dažādu šunnu jutības iespējamo atškirīibu jeb minēto metabolītu specifisko afinitāti.

Aminoskābes triptofāna fiziologiskās aktivitātes pētijjumi sākušies jau 19. gadsimteña vidū, kad noskaidrots, ka triptofāna trūkums uzturā izraisa negatīvu slāpek]̣ bilanci organismā [40,41]. No 1959./1960.gada zinām, ka triptofăns spēj paaugstināt leikocītu skaitu perifēriskajās asinīs [3 - 7], bet 1967. gadā uzzinām, ka triptofăns ir vienīgā aminoskābe, kas spēj aktivēt transporta RNS, kā arī aktīvi piesaistīties gan citazola, gan kodola olbaltumiem [42 - 46]. Šie dati apstiprina mūsu rezultātus par triptofăna ietekmi uz lipīdmainu fosfolipīdu biosintēzes laikā.

No literatūras zinām, ka 3-hidroksikinurenīnam un 3-hidroksiantranīlskābei ir endogēnas blastomogēnas īpašības [11], bet hinolīnskābei ir neirotoksiskas īpašības [47]. Turpretim nikotīnskābei ir daudz pozitīvu īpašību: tā paplašina koronāros un smadzenu asinsvadus, paaugstina kuṇga sekrēciju; to lieto pelagras, kã arī centrālo un perifērisko nervu toksiskā neirīta ārstēSanai [11] utt. Serotonīns fiziologiskās koncentrācijās izraisa asinsspiediena pazemināšanos un bradikardiju [48], bet trombocītos esošo serotonīnu uzskata par lokālu antioksidantu [49]. Serotonīns [50] un tā metabolīts melatonīns [51] ir minēti kā brīvo radikālu savācēji, tătad antioksidanti. Lielās koncentrācijās serotonīns asinsspiedienu izteikti paaugstina [48], kā arī izraisa arteriosklerotiskas izmaiņas koronārās artērijās un fibrotiskus sabiezinājumus trikuspidālās, mitrālās un aortālās vārstulēs suṇiem [52], pirkstu un astes nekrozi žurkām [53].

Pagaidām literatūrā maz datu par pterīnu jeb pteridīnu fiziologiisko aktivitāti, jo šo metabolītu pētīšana sākusies tikai 1963./ 1964. gadā [54]. Tomēr zināms, ka 5,6,7,8 - tetrahidrobiopterīns ir to hidroksilāžu kofaktors, kas pārvērš fenilalanīnu tirozīnā, tirozīnu - DOPA, bet triptofănu - 5-hidroksitriptofănā $[55,56,57]$. Tas ir arī NO sintetāzes kofaktors [58,59]. Tetrahidrobiopterīns, kā arī tā biosintēze nepieciešama mazdiferencēto gliomas šūnu PC-12 augšanai. Lai gan tetrahidrobiopterīna koncentrācija smadzenu gliomas šūnās atrasta zema, šis pteridīns veicina gliomas šunu augšanu un izdzīvošanu [60].

Homocisteīns veicina asinsvadu endotēlija un gludās muskulatūras šūnu augšanu $[61,62]$. Ja homocisteīna koncentrācija organismā ir paaugstināta, asinsvadu sienu biezums palielinās un asinsvadu intimas virspusē veidojas plātnītes, kas uzskatāmas par ķēdes locekli koronāro un citu artēriju trombozes izcelsmē [63]. Homocisteīna akumulēšanās galvenais cēlonis ir B6 vitamīna nepietiekamība, kā arī traucējumi B6 vitamīna aktīvās formas jeb P-5-F veidošanā. Šo pētījumu pirmsākums faktiski būtu datējams ar 1934. gadu, kad žurnālā Nature [1934, vol.133,p.498] P. Grygöry paziņoja par $\mathrm{B}_{6}$ vitamīna atklāšanu [cit.65]. Vēlāk kon- 
statēja, ka šis vitamīns nepieciešams sēra pārnešanai [64] un ka tã aktīvā forma P-5-F - ir kofaktors cistationīna- $\beta$-sintetāzei [65]. Bez tam konstatēja, ka pērtiķiem piridoksīna deficìta gadījumos rodas arteriosklerotiskas izmaiņas asinsvados, kā arī aknu un zobu bojājumi [66]. Tagad zinām, ka šo izmainuu cēlonis asinsvados ir traucējumi homocisteīna metabolismā [67]. Homocisteīns rodas no neizstājamās aminoskābes metionīna (7. att.) un tā uzkrāšanās asinīs novērojama tāpēc, ka visas fermentsistēmas, kas homocisteīnu pārvērš cisteīnā ir P-5-F atkarīgas [68]. Tāpēc homocisteinēmijas ārstēšanai lieto B6 vitamīnu, kas šūnās pārvērsdamies par P-5-F, aktivē inaktivētās fermentsistēmas. Var lietot arī betaīnu, kas, pievienojoties homocisteīnam pietiekama B12 vitamīna un folskābes gadījumā, homocisteīnu pārvērš metionīnā [68]. Šis alternatīvais homocisteīna līmeña pazemināšanas cệ̣̌ gan nebūtu uzskatāms par normālu, jo tad metionīns būtu pieskaitāms aizstājamo aminoskābju pulkam. Protams, organismā var trūkt arī to fermentsistēmu apofermenti, kas homocisteīnu pārvērš cisteīnā. Tă kā apofermenti ir specifiski olbaltumi, šădu homocisteinēmiju pagaidām nav iespējams ārstēt. To uzskata par iedzimtu patolog̀iju.

Mūsu pētījumos L-homocisteīns paaugstināja polinepiesātināto taukskābju ieslēgšanos fosfolipīdos biosintēzes laikā, kā arī paaugstināja fosfolipīdu līmeni paraugos. Uzskata, ja homocisteinēmiju pavada pazemināts fosfolipīdu daudzums organismā "antifosfolipīdu" sindroma dēl, tad arteriālās trombozes iespējamība tuvojas 100\% [69]. Tiesa, līdz 1998. gadam antivielas pret fosfolipīdiem nav identificētas. Uzskata, ja slimniekam atrod C-reaktīvo olbaltumu, antivielas pret kardiolipīnu un/vai lupus antikoagulantu, fosfolipīdu biosintēze ir traucēta. Tāpēc P-5-F nepietiekamības un fosfolipīdu biosintēzes pētījumiem būtu ierādāma īpaša vieta kardiovaskulāro slimību patog̉enēzē.

\section{Literatūra}

1. Рудзит В.К. О структурных изменениях брыжейки белой крысы // Изв. АН Латв. ССР. - 1953. № 8. - С. 85-91.

2. Рудзит К.К. Гепариноциты. - Рига: Изд. АН Латв. ССР, 1959. - С. 72-74.

3. Rudzīte $V$. Perifêro asiñu un saistaudu formelementi un seruma olbaltumi pie jaundabīgiem audzējiem (Klīniski un eksperimentāli pētījumi): Disertãcija. -Rīga, 1960. - 1. sēj. 325 lpp., 2.sēj. - 51 lpp. mašīnrakstã.

4. Rigó J., Takács F., Sós J. Effect of tryptophan on the leucocyte count // Acta Physiol. Acad.Sci.Hung. - 1959. - 15,1. - P. 83-89.

5. Rigó J. Sós J., Döklen A., Takács F. Die Wirkung von Tryptophan auf das Blutbild // Arch.Int.Pharmacodyn. - 1960, - 128, 3-4. - P. 491-495.

6. Rudzite V. Quantitative changes in the blood platelet and leucocyte counts, in the tryptophan content of serum protein in cases of malignant tumors (clinical and experimental observations) // Neoplasma. - 1963. - 10,1. - P. 35-44. 
7. Рудзит В.К. Пероральное действие триптофана на картину крови при лейкопениях // Изв.АНЛатв. ССР. - 1963. - № 5. -С. 113-120.

8. Рудзит В.К. Взаимосвязь между активностью триптофанпирролазы и декарбоксилазы 5-ОН триптофана и количеством тромбоцитов и лейкоцитов крови у крыс // Изв. АН Латв ССР. - 1968. - № 11. - С. 111-115.

9. Hardeland $R$. Complexity of in vivo induction of tryptophan oxygenase and tyrosine aminotransferase: effects of tryptophan metabolites // Comp. Biochem. Physiol. - 1973. -41B, 1. - P. 39-44.

10. Рудзит В.К. Особенности обмена триптофана при патологии: Дисс. на соискание ученой степени доктора медицинских наук. - Рига, 1968. - 444 с. машинописи.

11. Рудзит В.К. Триптофан (в норме и патологии). - Ленинград: Медицина, Ленинградское отделение, 1973.

12. Рудзит В.K. Определение белковосвязанного йода для диагностики функционального состояния шитовидной железы // Сб. трудов "Ученые медики - практике здравоохранения." - Рига, 1972. - С. 111-112.

13. Рудзит В.К., Бумейстер В.К., Больиевич Ж.А., Далмане А.Р. Увеличенная концентрация углекислого газа во вдыхаемом воздухе и функция щитовидной железы // Тез.докл. 3-го Всесоюзного конресса патофизиологов "Механизмы повреждения, резистентности, адаптации и компенсации”. - Ташкент, 1976. Том 1. - C. 339-339.

14. Bumeister V., Rudzite V., Dalmane A., Lerhs E., Bolshevich Z. Development of goiter as a manifestation of adaptation mechanism of organism // Abstracts of the 3rd International Congress of Pathophysiology. - Varna, 1978. - P. 8-8.

15. Рудзит В.К., Силиня И.Я. К методу определения кинуренина в крови // Лаб.Дело. - 1980. - № 4. - С. 219-222.

16. Silinga I. Fiziskās slodzes ietekme uz vairogdziedzera aktivitāti, kã arī tirozīna un triptofāna vielu maiṇu: LVU Ķīmijas fakultātes diplomdarbs. - Rīga, 1976. - 99 Ipp. mašinnrakstā.

17. Rudzīte V., Muižniece I., Sileniece G., Dālmane A., Jurika E. Delayed human cardioprotection after exercise due to accumulation of kynurenine (supported by additional experiments on isolated hearts) // Proc.LatvianAcad.Sci. - 1999. -53,4. - P. 225-226.

18. Schöberberger W., Hobish-Hagen P., Wiederemann F, Rieder J, Hoffmann G., Herold M., Fuchs D. Immune activation during extreme induced endurance exercise // Pteridines. - 1998. -9. - P. 166-167.

19. Ito Y., Murata K., Nakagami Y., Koike T., Oguri Y., Nagamura Y., Saito K. Kynurenine concentration was increased by exercise // Adv. Exp.Med.Biol. - 1999. -467 . - P. 717-722. 
20. Рудзит В.К. Диабетогенные метаболиты триптофана как причина сахарной болезни. - Рига: Зинатне, 1981.

21. Горяченкова E.B. Витамин В 6 (пиридоксин) // Витамины/под ред. М.И.Смирнова. - Москва: Медицина, 1974. - С. 236-263.

22. Рудзит В.К., Лацис Я.В., Тирума Б.Я., Балтиня И.Б., Биедрис И.А. Кивлениеце Д.Э. Способ диагностики ишемической болезни сердца // Изобретения СССР и за рубежем (МКИ А-61). - 1984. - Вып. 13, № 9. - С. 4-4.

23. Рудзит В.К., Лачис Я.В., Тирума Б.Я. Способ лечения ишемической болезни сердца // Бюллетень Гос. Комитета по делам изобретений и открытий (МКИ A-61). - 1984. - № 22. - C. 23-23.

24. Иргенсон Я.Б. Нарушения эндогенного образования никотиновой кислоты при ишемической болезни сердца: Дисс. на соискание ученой степени канд.мед.наук. - Рига, 1986. -167 с. машинописи.

25. Скардс Я.И. Нарушения кинуренинового пути межуточного обмена тригтофана у больных дилятационной и гипертрофической кардиомиопатией: Дисс. на соискание ученой степени канд.мед.наук. - Рига. 1991. - 123 с. машинописи.

26. Rudzite V., Sileniece G., Jirgensons J., Skards J., Zirne R., Dalmane A. Bradyarrythmias and miocardial cell failure induced by kynurenine // Progress in Tryptophan and Serotonin Research 1986 / D.A. Bender, M.H. Joseph, W. Kochen, H. Steinhart eds., Walter de Gruyter. - Berlin; New York, 1987. - P. 131-136.

27. Капелько Б.И., Попович М.И., Костин С.И., Гудимак Б.С., Голиков М.А, Новикова Н.А., Шаров В.С., Сакс В.Ф. Изменения в функции сердца, метаболизме и ультраструктуре при экспериментально вызванной кардиомиопатии // Тез. докл. 4-го Всесоюзного конгресса патофизиологов. Кишинев; Москва, 1989. - 3. - С. 969-969.

28. Feldkamp H., Muerer K. A., Godehart E. Tryptophan induced lowering blood pressure and changes in serotonin uptake by platelets in patients with essential hypertension // Klin. Wochenschr. - 1984. -62. - P. 1115-1119.

29. Rudzite V., Jurika E., Arajs J., Andrejev N. The relationship between kynurenine and arterial blood pressure // Progress in Tryptophan and Serotonin Research 1986 / D.A. Bender, M.H. Joseph, W. Kochen, H. Steinhart eds., Walter de Gruyter. Berlin; New York, 1987. - P. 126-130.

30. Рудзит В.К., Андреев Н.Н., Арайс Я.А, Юрика Э.В., Скарда И.Я. Способ диагностики гипертонической болезни // Бюлл.Открытия, изобретения. 1988. - № 20. - C. 13-13.

31. Мартинсонс А.Ю. Особенности кинуренинового пути межуточного обмена триптофана у больных хроническим гломерулонефритом: Дисс. на соискание ученой степени канд. мед. наук. - Рига, 1991. - 150 с.машинописи. 
32. Rudzīte V., Sileniece G., Jurika E., Martinsons A., Dalmane A., Groma V., Vitolina $L$. Kynurenine and the development of heart and renal pathology // Advances in Tryptophan and Serotonin Research 1992 / I. Ishiguro, R. Kido, T. Nagatsu, Y. Nagamura, Y. Ohta eds. - Fujita Health University Press, Toyoake, 1992. - P. 370-382.

33. Martinsons A. L-triptofầna vielmaiṇas kinurenīna ceja nozīme dažādu hronisku glomerulonefrīta formu attīstībā: Disertācija med. habilitētā doktora grāda iegūšanai. - Rīga, 1998. - 77 lpp. datorrakstā.

34. Ostro M.J., Bessinger B., Summers J., Dray S. Effect of membrane lipid composition on mobility of lymphocyte surface immunoglobulins // Membrane Fluidity. Biophysical Techniques and Cellular Regulation / M.Kates, A-Kuksis eds. Clifton, 1980. - P. 105-117.

35. Ferber E., Kröner E., Schmidt B., Ficher H., Peskar B.A., Anders C. Dynamics of membrane fatty acids during lymphocyte stimulation by mitogens // Membrane Fluidity. Biophysical Techniques and Cellular Regulation / M.Kates, A Kuksis eds. - Clifton, 1980. - P. 239-263.

36. Takikawa O., Kuroiwa T., Yamazaki F., Kido R. Function and regulation of extrahepatic tryptophan pyrrolase (indolamine- 2,3- dioxygenase): studies of its induction by interferon-ã. In: Progress of Tryptophan and Serotonin Research 1986 / D.A.Bender, M.H.Joseph, W Kochen, H.Steinhart eds. - Walter de Gruyter, Berlin; New York. 1987. - P. 47-50.

37. Rudzite V., Jurika E., Baier-Bitterlich G, Widner B., Reibnegger G, Fuchs D. Pteridines and lipid metabolism // Pteridines. - 1998. - 9. - P. 103-112.

38. Okamoto $H$. Effect of quinaldic acid and relatives on insulin-release from Langerhans islets // Acta Vitaminol. Enzymol. - 1975. - 29, 1-6. - P. 227-231.

39. Versio L., Seleti A, Radzioch D.,Pulkki K., Brooks A, Gusella G.L., Bosco M.C., Fomi G. Picolinic acid and its influence on the immune system // L-Tryptophan Current Prospects in Medicine and Drug Safety / W.Kochen, H.Steinhart eds. Walter de Gruyter, Berlin; New York, 1994. - P. 99-110.

40. Albanese A.A., Randal R.Mcl, Holt L.E. The influence of tryptophan deficiency on reproduction // Science. - 1943. - 97. - P. 312-515.

41. Albanese A.A. Protein and amino acid requirement of mammals. - New York: Acad Press, 1950.

42. Sidransky H., Bongiomo M., Sarma D. S.R, Vemey E. The influence of dietary tryptophan on hepatic polyribosomes and protein synthesis in fasted mice // Biochem.Biophys.Res.Comm. - 1967. - 27. - P. 242-252.

43. Sidransky H., Sarma D.S.R, Bongiomo M., Vemey E. Effect of dietary tryptophan on hepatic polyribosomes and protein synthesis in fasted mice // J.Biol.Chem. 1968. - 243. - P. 1123-1125. 
44. Sidransky H. Tryptophan, unique action by essential amino acid // Nutritional Pathology. Pathobiochemistry of Dietary Imbalance / H. Sidransky eds. - New York: Marcel Decker Inc., 1985. - P. 1-30.

45. Sidransky H., Vemey E., Murty C.V. Studies of the influence of tryptophan and related compounds of hepatic polyribosomes and protein synthesis in rat // J.Nutrition. - 1980. - 110. - P. 2231-2242.

46. Sydransky H., Kurl R. V., Vemey E., Cosgrove J.W., Schwartz A.M. Tryptophan binding to nuclear membrane receptor // L-Tryptophan Current Prospects and Drug Safety. / W.Kochen, H.Steinhart eds. - Berlin; New York, 1994. - P. 31-39.

47. Heyes M.P. The kynurenine pathway and neurologic disease: Therapeutic strategies // Adv. Exp.Med.Biol. - 1996. - 398. - P.125-129.

48. Me Call R.B., Clement M.E. Role of serotonin1A and serotonin2 receptors in the central regulation of cardiovascular system // Pharmacol.Reviews. - 1994. - 46. P. 231-243.

49. Heuther G., Schuff-Werner P. Platelet serotonin acts as releasable antioxidant // Adv.Exp.Med.Biol. - 1996. - 398. - P. 299-366.

50. Hardeland R., Behrmann G., Fuhrberg B, Poeggeler B., Burkhardt S., Uria H., Obst B. Evalutionary aspects of indolamines as radical scavengers /I Adv.Exp.Med.Biol. - 1996. - 398. - P. 279-284.

51. Reiter R.J. The indolamine melatonin as a free radical scavenger, electron donor and antioxidant // Adv. Exp.Med.Biol. - 1996. - 398. - P. 307-313.

52. Rossi P., Stevenson M., Khaksar P., Ballet S. Coronary arteriosclerosis in young dogs after prolonged interaortic infusion of serotonin // Circulation Res. - 1961. 9. - P. 439-440,

53. Mc Donald R.A., Robbins S.L., Mallory K. Morphologie effects of serotonin /I Arch. Pathol. - 1958. - 65. - P. 369-377.

54. Wächter H., Fuchs D., Hausen A., Reibnegger G., Weiss G, Werner E.R, WernerFelmayer G. Neopterin. Biochemistry, Methods, Clinical Application. -Berlin; New York: Walter de Gruyter, 1992.

55. Kaufman $S$. The structure of phenylalanine cofactor// Proc.Natl.Acad.USA - 1963. - 50. - P. 1085-1093.

56. Shiman R., Akino M., Kaufman S. Solubilization and partial purification of tyrosine hydroxylase from bovine adrenal medulla // J.Biol.Chem. - 1971. - 246. - P. $1330-1340$.

57. Friedman P.A., Kapelman H., Kaufman S. Partial purification and characterization of tryptophan hydroxylase from rabbit hindbrain // J.Biol.Chem. - 1972. - 247. P. 4165-4173.

58. Tayeh M. A., Marietta M. A. Macrophage oxidation of L-arginine to nitric oxide, nitrite and nitrate // J.Biol.Chem. - 1989. - 264. - P. 19654-19658. 
59. Kwon N.S., Nathan C.F., Stuehr D.I. Reduced biopterin as cofactor in the generation of nitrogen oxides by murine macrophages // J.Biol.Chem. - 1989. - 264. - P. 20496-20501.

60. Bezin L., Anastasiadis P.Z., Corcoran G.B., Bygaard T.G, Levine R.H. Tetrahydrobiopterin metabolism in cell death by apoptosis // Chemistry and Biology of Pteridines and Folates. - Berlin; Vienna: W.Pfleiderer, H.Rokos eds, 1997. - P. 749-750.

61. Ueland P.M. Plasma homocysteine and cardiovascular disease // Atherosclerotic cardiovascular disease end endothelial function / R. Francis eds., Marcel Dekker. New York, 1990. - P. 183-236.

62. Tsai J.C., Perrella M.A., Yoshizumi M. Promotion of vascular smooth muscle cell growth by homocysteine a link to atherosclerosis // Proc.Nat.Acad.Sci. - 1994. 91, 14. - P. 6396-6373.

63. Zhou J.I., Chew M., Ravin H.B., Falk E. Plaque pathology and coronary trombosis in the pathogenesis of acute coronary syndrome // Scand.J. Clin.Lab.Investig. 1999. - 59 (Suppl.230). - P. 3-11.

64. Binkley F., Christensen G.m., Jensen W.N. Pyridoxine and the transfer of sulphur // J.Biol.Chem. - 1952. - 194. - 101-113.

65. Майстер A. Биохимия аминокислот. - Москва: Изд.иностр.лит., 1961. - С. $164-306$.

66. Greenberg L.D. Arteriosclerotic, dental and hepatic lesions in pyridoxine-deficient monkeys // Vitamines and Hormones. - 1964. - 22. - P. 677-689.

67. Brattstrom I., Israelsson B., Norving B., Bergquist P., Thome J., Hultberg B., Hamfelt $A$. Impaired homocysteine metabolism in arterial disease // Atherosclerosis. - 1988. - 81, - P. 51-60.

68. Ubbink J.B., van der Merwe A.,Delport R., Allen R.H., Stabler S.P., Riezeer R, Hayward Vermaak W.J. The effect of a subnormal vitamin B6 status on homocysteine metabolism // J.Clin.Investig. - 1996. - 98. - P. 177-184.

69. Kandiah D.A, Sali A, Sheng Y., Victoria E.J., Marquis D.M, Courts S.M., Krilis S.A. Current insights in the "antiphospholipid" syndrome: clinical, immunological, and molecular aspects // Advances in Immunology. - 1998. - 70. - P. 507-563. 


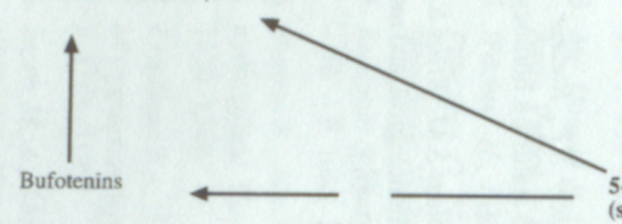

-hidroksitriptamins (serotonins)

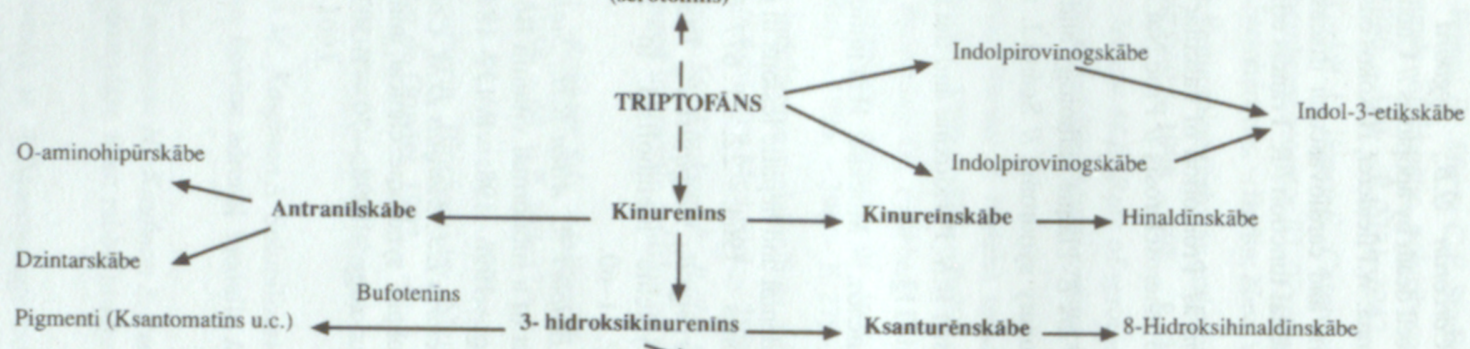

Pigmenti (Ksantomatins u.c.)

3- hidroksikinurenins

Ksanturènskâbe

8-Hidroksihinaldinskãbe

Hidroksiant

Pikolinskảbe Mukons

$\alpha$-Mukonskābes $\beta$-pusaldehids

Glutaminskābe
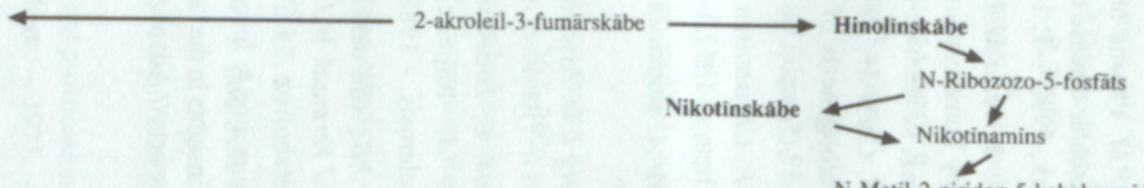

1. attēls. Triptofăna metabolisms

N-Metil-2-piridon-5-kaboksamids

Figure 1. Tryptophan metabolism 

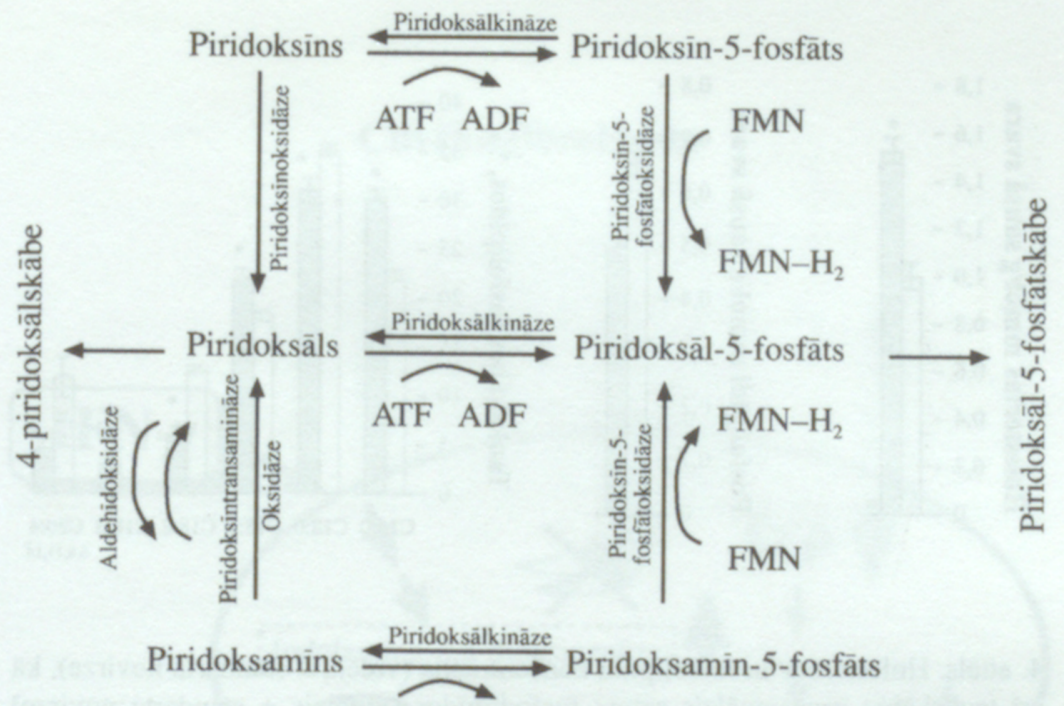

ATF ADF

2. attēls. $\mathrm{B}_{6}$ vitamīna (piridoksīna) metabolisms. * ATF-adenozīntrifosfăts; ADFadenozīndifosfăts; FMN- flavīnmononukleotīds; FMN-H2 - reducētais flavīnmononukleotīds

Figure 2. Pyridoxine metabolism

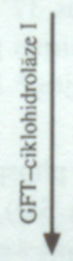

7,8 - dihidroneopterinatrifosfâts 7,8 - dihidroneopterīns
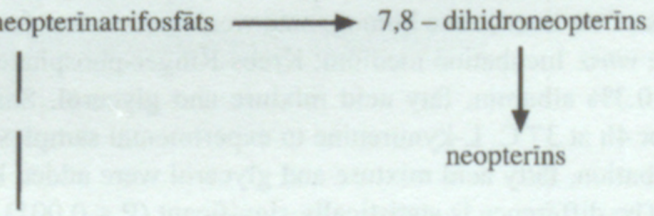

neopterins

7,8- dihidroneopterinatrifosfats

3. attēls. Pteridīnu metabolisms. GTF - guanozīna trifosfāts

Figure 3. Pteridin metabolism 

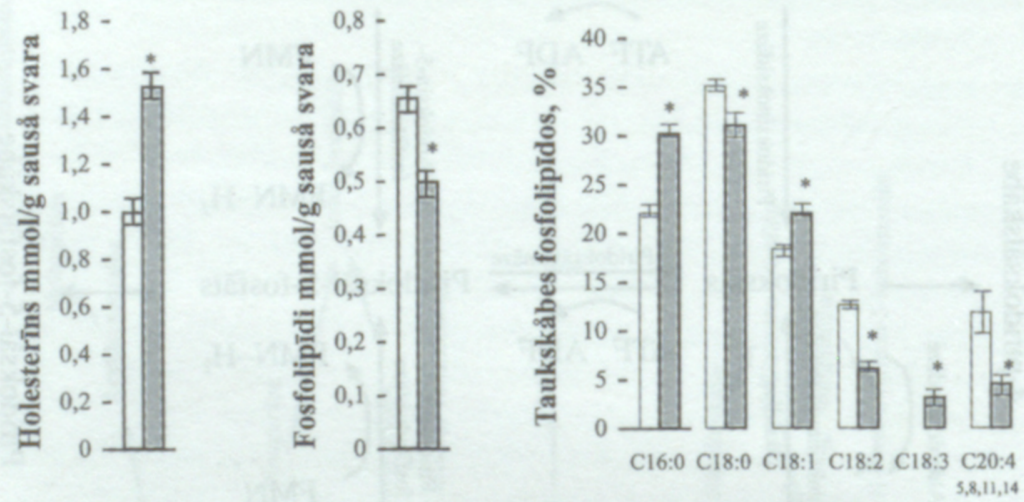

4. attēls. Holesterīna un fosfolipīdu koncentrācija (vidējā \pm standarta novirze), kā arī taukskābju procentuālais saturs fosfodlipīdos (vidējais \pm standarta novirze) kontroles paraugos (gaišie stabiṇi) un paraugos, kas saturēja 4 nmol L- kinurenī$\mathrm{na} / \mathrm{g}$ mitrā svara (iesvītrotie stabiņi). Fosfolipīdu biosintēzes noteikšanai in vitro lietots: intaktu balto Wistar līnijas žurku aknu homogenāts Krebsa - Ringera - fosfăta bufera ( $\mathrm{pH}=7,4)$ šḳīiumā, kas saturēja $0,3 \%$ albumīna; taukskābju (palmitīnskābe, stearīnskābe, oleīnskābe, linolskābe, linolēnskābe, arahidonskābe līdzīgās da|ās) maisījums un glicerīns. Paraugi inkubēti 4 stundas $37^{\prime}$ tempe-ratūrā divas reizes. Kinurenīns pievienots eksperimenta paraugiem pirms pirmās inkubācijas, tauksābju maisījums un glicerīns - pirms otrās inkubācijas. ${ }^{*}$ Rezultātu diference ir statistiski ticama $(\mathrm{P}<0,001)$

Figure 4. Concentration (mean $\pm \mathrm{SD}$ ) of cholesterol and phospholipids as well as fatty acid content of phospholipids (in percent: mean \pm SD) in control samples (open bars) and in samples with $4 \mathrm{nmol} \mathrm{L-kynurenine/g} \mathrm{wet} \mathrm{weight} \mathrm{(hatched} \mathrm{bars).}$ Samples of rat liver tissue homogenate were used to test for phospholipid biosynthesis in vitro. Incubation medium; Krebs-Ringer-phosphate buffer $(\mathrm{pH}=7,4)$ containing $0.3 \%$ albumin, faty acid mixture and glycerol. Samples were incubated twice for $4 \mathrm{~h}$ at $37^{\circ} \mathrm{C}$. L-kynurenine to experimental samples was added before the $1^{\text {st }}$ incubation, fatty acid mixture and glycerol were added before the $2^{\text {nd }}$ incubation. ${ }^{*}$ The difference is statistically significant $(\mathrm{P}<0.001)$ 


\section{Cilvēka fibroblasts}

\section{IFN- $\gamma$}

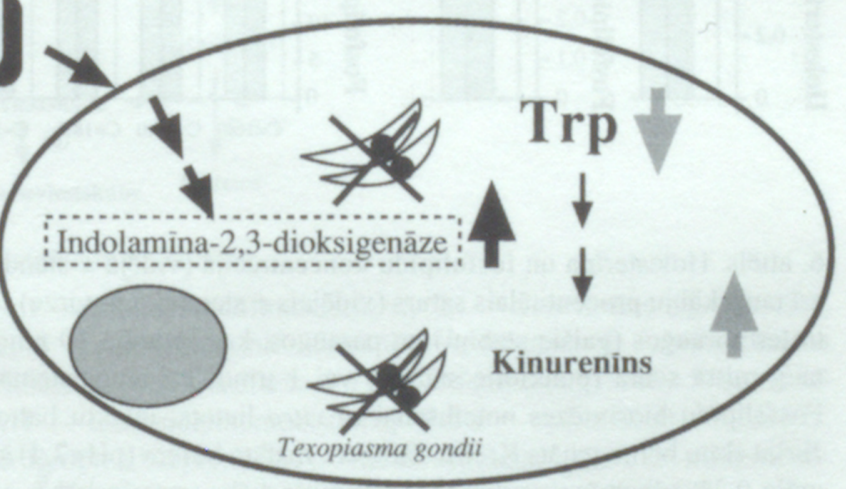

5. attēls. Interferona- $\gamma$ antiparazītiskās aktivitātes izpausme cilvēka fibroblastā. * IFN- $\gamma$ - interferons- $\gamma$; Trp - triptofans

Figure 5. Mechanism of anti-parasitic activity of interferon- $\gamma$ 

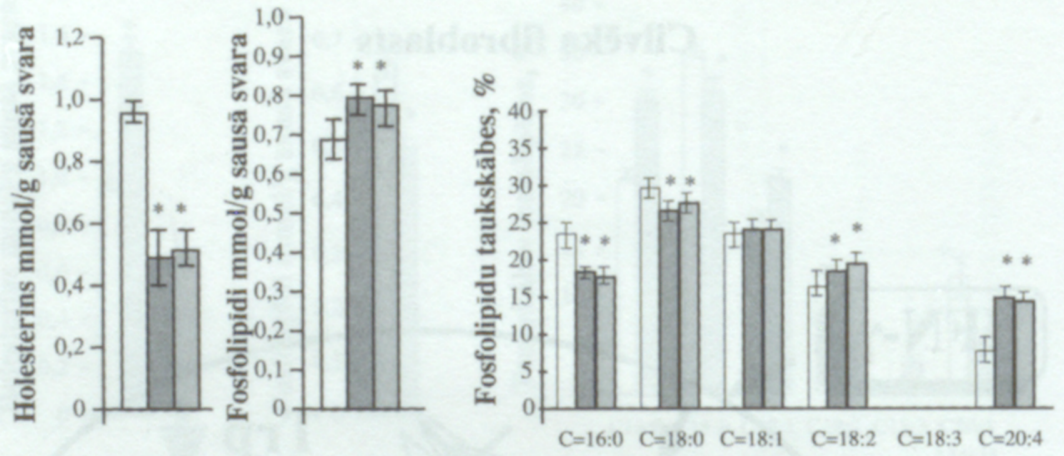

6. attēls. Holesterīna un fosfolipīdu koncentrācija (vidējā \pm standarta novirze), kā arī taukskābju procentuālais saturs (vidējais \pm standarta novirze) fosfolipīdos kontroles paraugos (gaišie stabiṇi) un paraugos, kas saturēja $10 \mathrm{nmol}$ L-homocisteīna/g mitrā svara (punktotie stabiṇi) vai $1 \mu \mathrm{mol}$ L-homocisteīna/ g mitrā svara. Fosfolipīdu biosintēzes noteikšanai in vitro lietots: intaktu balto Wistara līnijas žurku aknu homogenāts Krebsa-Ringera fosfăta bufera $(\mathrm{pH}=7,4)$ šḳīdumā, kas saturēja $0,3 \%$ albumīna; taukskābju (palmitīnskābe, stearīnskābe, oleīnskābe, linolskābe, linolēnskābe, arahidonskābe līdzīgās da|ās) maisījums un glicerīns. Paraugi inkubēti 4 stundas $37^{\circ} \mathrm{C}$ temperatūrã divas reizes. L-homocisteīns pievienots eksperimenta paraugiem pirms pirmās inkubācijas, taukskābju maisījums un glicerīns - pirms otrās inkubācijas. Diference ir statistiski ticama $(\mathrm{P}<0,01)$

Figure 6. Concentration (mean $\pm \mathrm{SD}$ ) of cholesterol and phospholipids, as well as fatty acid content ( in percent; mean $\pm \mathrm{SD}$ ) of phospholipids in control samples (open bars) and in samples with $10 \mathrm{nmol}$ L-homocysteine/g wet weight (dotted bars), or with 1 gmol L-homocysteine/g wet weight (hatched bars). Samples of intact rat liver tissue homogenate were used to test for phospholipid biosynthesis in vitro. Incubation medium: Krebs-Ringer-phosphate buffer $(\mathrm{pH}=7.4)$ containing $0.3 \%$ albumin, fatty acid mixture and glycerol. Samples were incubated twice for $4 \mathrm{~h}$ at $37^{\circ} \mathrm{C}$. L-homocysteine to experimental samples was added before the $1^{\text {st }}$ incubation, fatty acid mixture and glycerol were added before the $2^{\text {nd }}$ incubation. The difference is statistically significant $(\mathrm{P}<0.01)$ 

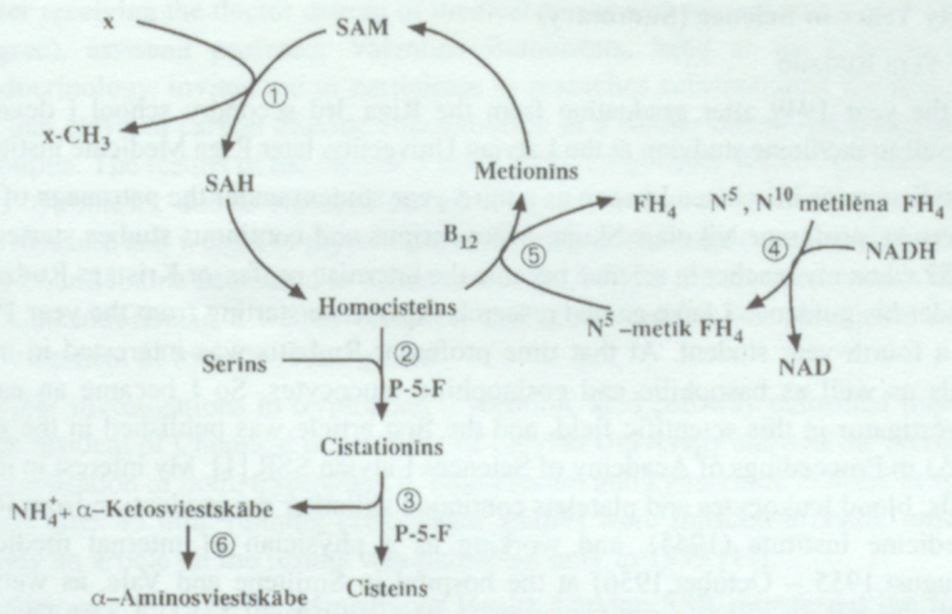

7. attēls. Homocisteīna metabolisms

Paskaidrojumi: 1 -dažādas metiltransferāzes; 2 - cistationīna - $\beta$-sintetāze; 3 - cistationāze; 4 - metilēntetrahidrofolskābes reduktāze; 5 - homocisteīna 5-metiltetrhidrofolskābes metiltransferāze; 6 - transferāze(s); SAM - S-adenozilmetionīns; SAH - S-adenozilhomocisteīns; P-5-F - piridoksāl -5-fosfăts; $\mathrm{x}$ - parastie metilgrupu akceptori; FH4 -tetrahidrofolskābe; NAD-nikotīnamīdadenīndinukleotīds; N.ADH-reducētais nikotīnamīdadenīndinukleotīds

Figure 7. Homocysteine metabolism 


\section{Fifty Years in Science (Summary)}

By Vera Rudzite

In the year 1949 after graduating from the Riga 3rd secondry school I devoted myself to medicine studying at the Latvian University, later Riga Medicine institute.

The first steps in science I began as a third-year student under the patronage of the internist, professor Nikolajs Skuja. More serious and continous studies started in 1952 when my teacher in science became the internist, professor Kristaps Rudzitis. Under his guidence I have gained research experience starting from the year 1952 as a fourth-year student. At that time professor Rudzītis was interested in mast cells as well as basophilic and eosinophilic leucocytes. So I became an eager investigator in this scientific field, and the first article was published in the year 1953 in Proccedings of Academy of Sciences Latvian SSR [1]. My interest in mast cells, blood leukocytes and platelets continued still after the graduation from Riga Medicine institute (1955), and working as a physician of internal medicine (August,1955 - October,1956) at the hospital in Smiltene and Vale, as well as being as a researcher of the Latvian institute of Experimental and Clinical Medicine ( October 1956 - February 1979). Only later investigations in proteins and essential amino acid tryptophan attracted my interest.

The results observed in the years 1958/1959 about tryptophan concentration of serum albumin fraction (this fraction contained albumin tryptophan, with albumin bound tryptophan and free tryptophan) and blood leukocytes and platelets counts formed the basis of my thesis "Blood and connective tissue cells and proteins in malignant tumors (Clinical and experimental investigations)" [3] to obtain the degree of candidate of medical sciences in December 19, 1960 in the speciality of internal medicine at the Scientific Council of Riga Medicine institute. It was approved by the Highest Attestation Committee of USSR in February 15, 1961. An article on this discovered relationship in English was published in 1963 in Neoplasma [6]. At that time the use of tryptophan has been started in cases of leukopenia [7].

Further studies in white Wistar rats showed that both, tryptophan and its metabolites [Figure 1] activated serotonin and especially kynurenine pathway of tryptophan metabolism by increasing activity of tryptophan-2,3-dioxigenase and 5hydroxytryptophan decarboxylase in liver and thus participating in the formation of relationships between tryptophan metabolism and blood cells. These results combined with the data of literature formed the basis of the $2^{\text {nd }}$ thesis "Tryptophan metabolism in pathology" [10]. It was defended in October 14, 1969 in the speciality of pathophysiology at the Scientific Council for Physiology, Biochemistry and Pharmacology Academy of Medical Sciences USSR and approved by the Highest Attestation Committee of USSR in February 19, 1971. The $1^{\text {st }}$ monograph "Tryptophan (in normal and pathological conditions)" published in the year 1973 [11] by Medicine, Leningrad also included the results obtained during these studies. 
After receiving the doctor degree of medical science (at present habilitated doctor degree), assistant professor Valentins Bumeisters, head of the laboratory of Endocrinology, invited me to participate in reseaches substantiating the hypothesis that elevated carbon dioxide concentration in a wether breath induced a goiter in pupils. The results of the further 3 years received in white Wistar rats confirmed this hypothesis: due to elevated carbon dioxide concentration in a wether breath the measure and weight of thyroid gland increased, while the concentration of protein bound iodine decreased in blood serum $[13,14]$. So the elevated carbon dioxide concentration in a wether breath is one of the factors that participate in the development of hypothyreotic goiter.

Further investigations in tryptophan - nicotinic acid pathway peformed together with resident of Chemical department of Latvian University showed the increased concentration of both, tryptophan in blood serum and kynurenine in urine in sportmens after $45 \mathrm{~min}$. running [16]. These studies were finished in 1976, unfortunately an article on the results was published only in 1999 [17].

In February 5, 1979 the Ministry of Health Latvian SSR transferred me to the Latvian institute of Cardiology founded in 1977. Alongside building the laboratory (the $4^{\text {th }}$ in my life) the $2^{\text {nd }}$ monograph "Diobetogenic metabolites of tryptophan in the development of Diabetes mellitus" was written. It was published in the year 1981 [20].

The leaders of Latvian institute of Cardiology allowed me to continue the investigations in tryptophan - nicotinic acid pathway. Therefore after getting affirmation for this project in cardio-vascular pathology by the Highest Scientific and Technique Committee of USSR the laboratory of Biochemistry in Latvian institute of Cardiology was set up. The Scientific Council of the institute elected me as a chief of this laboratory.

The results received in patients with cardiovascular diseases allowed to suggest that kynurenine accumulation in blood serum at fasting state and after L-tryptophan loading takes part in the development of angina pectoris and stenocardia . This discovery was affirmed by pharmacological experiments on isolated hearts: kynurenine and its metabolites addition to incubation medium for isolated frog hearts induced attacks of bradycardia, extrasystoles and cardiac arrest at the beginning of diastole. At that time because of the lack of the Holter monitoring method in cardiological wards of our hospital it was only affirmed by answers of patients experiencing bradycardia and cardiac arrest at the time of their attacks.

Increased kynurenine accumulation at fasting state and after L-tryptophan loading was also observed in patients with sinus bradicardia, sinus node disease, chronic atrioventricular block [24], as well as in hypertrophic and dilation form of cardiomyopathy [25]. This discovery was interpreted as a manifectation of pyridoxal -5- phosphate / $\mathrm{P}-5-\mathrm{P} /$ deficiency (Figure 2) and/or activated immune system (Figure 3 ) observed in these patients. Firstly this interpretation was based on the 
possibility to activate by cytokines both, indolamine -2,3-dioxigenase in tissue cells and guanosine triphosphate /GTP/ cyclohydrolase I in macrophages followed by increased concentration of kynurenine and neopterin in body fluids. Secondly it was based on the possibility of inactivation of P-5-P dependent enzyme systems in P-5-P deficiency. These enzyme systems cleaved kynurenine and 3-hydroxikynurenine.

The results received in light and electronomicroscopic studies of isolated hearts after addition of kynurenine [26] and neopterin [37] to incubation medium allow to suggest that kynurenine and neopterin induced changes in cardiomiocytes characteristic to those observed in cases of increased calcium accumulation in cells and calcium dependent cell distrophy followed by apoptosis. Moreover it is known from literature, that interferon- $\varphi$ antiparasitic activity in human fibroblasts (Figure 5) is realized through kynurenine accumulation [36].

Nevertheless, German authors had reported that tryptophan lowered blood pressure in patiens with essential hypertension [28], in cases of increased serum kynurenine accumulation of patients with essential hypertension the tryptophan load test was followed by an elevation of systolic and diastolic blood presure as well as by increased norepinephrine concentration in serum. Direct kynurenine influence on norepinephrine concentration was also affirmed in vitro: $1 \mathrm{~h}$ incubation of human blood serum together with kynurenine in termostat at $37^{\circ} \mathrm{C}$ was followed by significant increase of norepinephrine concentration in experimental samples if compare with control [29].

Increased kynurenine accumulation in blood serum after L-tryptophan loading observed in part of patients with essential hypertension was also followed by decreased excretion function of kidneys, verified by the method of dynamic scintigraphy. Light and electronomicroscopic analysis of renal bioptate in such cases showed the mesangial-proliferative glomerulonephritis. In other forms of glomerulonephritis the kynurenine accumulation in blood serum after L-tryptophan loading was not observed [31]. Relationship between kynurenine accumulation and mesangial-proliferative glomerulonephritis was partly affirmed by results received in experiments with human fibroblast cultures: L-kynurenine addition to these cell cultures did not change the count of cells, but elevated the number of cells containing $\mathrm{H} 3$ thymidine $[32,33]$. So we suggested that kynurenine activated these cells.

Studies of lipid metabolism in patients with cardiovascular diseases were followed by dividing the received results into 2 groups: the $1^{\text {st }}$ group included the results received from patients without P-5-P deficiency (patients with normal accumulation of kynurenine in blood serum after l-tryptophan loading); the $2^{\text {nd }}$ group comprised results received from patients with P-5-P deficiency (patients with increased kynurenine accumulation in blood serum after L-tryptophan loading). We did not observe the difference between these two groups of patients in serum total choles- 
terol and HDL-cholesterol concentration. In both groups of patients the concentration of total cholesterol was elevated, while the concentration of HDL-cholesterol was lowered. The difference was identified in tryglicerol and phospholipid concentration of serum: an increase in concentration of tryglicerol and a decrease in concentration of phospholipids was found in blood serum of patients with $\mathrm{P}-5$-P deficiency. Further studies showed a decrease in percentage of phosphtidylcholine (lecithin) and unsaturated fatty acid content and an increase in phosphatidylserine and saturated fatty acid content of such phospholipids. Similar quantitative and qualitative changes in red cells phospholipids of such patients were observed, too. Moreover in white Wistar rats with experimentally induced P-5-P deficiency we observed changes in lipids of blood serum, liver, kidney and heart tissue similar to those found in patient with P-5-P deficiency.

The results obtained using the method for phospholipid biosynthesis in vitro allowed us to suggest, that P-5-P per se did not alter fatty acid incorporation into phospholipids as well as cholesterol and phospholipids concentration in samples. Deviations in lipids were induced by metabolites that accumulate in body fluids due to P-5-P deficiecy and/or activated immune system. At present we have examined L-tryptophan, 15 metabolites of it, 9 pteridines, norepinephrine and L-homocysteine effect on lipid metabolism due to phospholipid biosynthesis in vitro. Part of the above-mentioned metabolites did not alter lipid metabolism, whereas others induced different changes. Such as kynurenine (Figure 4), kynurenic acid xanthurenic acid, anthranilic acid, picolinic acid, 5-hydroxyindoleacetic acid, neopterin and norepinephrine induced a decrease of polyunsaturated fatty acids incorporation into phospolipids in exsamples used for phosphlipid biosynthesis in vitro. The concentration of cholesterol increased, while the concentration of phospholipids decreased or remained unchanged. So the cholesterol/ phospholipids ratio increased. From the data of literature $[34,35]$ we know that such changes in lipids are followed by a decrease of cell membranes fluidity, depressed cell cycle, calcium accumulation in cell and calcium dependent cell dystrophy, as well as possibile development of cholesterol precipitation.

The addition of such metabolites as L-tryptophan, 3-hydroxykynurenine, 3-hydroxyanthranilic acid, quinolinic acid, nicotinic acid, serotonin (if added to experimental samples together with MAO inhibitor ipraniasid), acethylserotonin, melatonin, sepiapterin, 7,8-dihydrobiopterin, 5,6,7,8-tetrhydrobiopterin, 7,8-dihydroneopterin and L-homocysteine (Figure 6) to incubation medium for phospholipid biosynthesis in vitro induced an inverse relationship. They induced a decrease of saturated and an increase of polyunsaturated fatty acids, especially arachidonic acid, incorporation into phospholipids. The cholesterol concentration decreased, while phospholipids concentration increased or did not alter in samples. So the cholesterol/phospholipid ratio decreased. From the data of literature $[34,35]$ we know, that such changes in lipids are followed by an increase of membrane fluidity, activation of cell cycle, also transformation of cells, as well as promotion to 
keep cholesterol in the state of solution. However both, the sensitivity of different cells to different metabolites and affinity of different metabolites to different cells have not been solved yet. So, further investigations are required.

Our results received in examination of homocysteine effect on phospholipid biosynthesis in vitro showed that homocysteine induced an increase of membrane fluidity and can activate cell cycle. So, these results agree with the data of literature concerning to endotelial and smooth muscle cells as well as arteriosclerotic changes in blood vesels $[61,62,63]$. However it can't promote cholesterol precipitation, while the other metabolites that accumulate in body fluids due to P-5-P deficiency and/or activated immune system, such as kynurenine, kynurenic acid, xanthurenic acid, anthranilic acid, picolinic acid, 5-hydroxyindoleacetic acid, neopterin and norepinephrine can do it. So, homocysteine is only an important link to atherosclerosis development. Usually it accumulates in body fluids due to P-5-P deficiency: all ezyme systems that cleave homocysteine to cysteine are $\mathrm{P}-5-\mathrm{P}$ dependent (Figure 7). Therefore vitamin B6 is necessary for normalization of homocysteine concentration in body fluids [68]. Betaine may also be used, which in cases of vitamin B12 and foleate normal levels can convert homocysteine to methionine again [68]. It is known that methionine is an essential amino acid [65]. So, in healthy individuals this pathway is doubtful, while in inherited and obtained homocysteinemia it can keep the homocysteine in normal concentration within a short period of time. If homocysteinemia is followed by a decreased level of phospholipids in organism due to "antiphospholipid" syndrome, development of arterial thrombosis is observed [69]. Nevertheless antibodies against phospholipids are not discovered till 1998, the presence of C-peptide, antibodies to cardiolipin and/or lupus anticoagulant are mentioned as factors that impair phospholipid biosynthesis. Therefore the studies of P-5-P deficiency as well as phospholipid biosynthesis are especially important for getting new information on pathogenesis of different cardiovascular diseases.

Vera Rudzīte, Dr habil. med., profesore, LZA akadēmiķe Kalvenes 19-1

Rīga, LV-1058

Latvija 